\title{
Understanding Wisdom in the Old Testament through Its Akan (Ghana) Parallels: Linkages and Disconnections
}

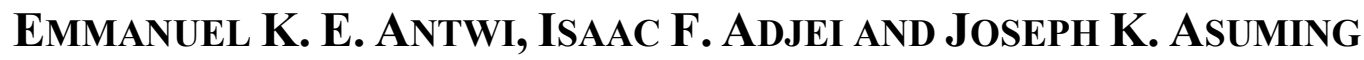 \\ (KWAME NKRUMAH UNIVERSITY OF SCIENCE AND TECHNOLOGY) ${ }^{1}$
}

\begin{abstract}
Explaining and interpreting biblical concepts in different cultures without due regard to the cultures of the biblical world have some challenges. When caution is not taken, one stands a chance of imposing one's cultural worldview on the biblical text. Understanding of the concepts in one's culture could be useful in helping him or her grasp the meanings of the biblical concepts. This paper delves into wisdom in the OT and that of the Akan of Ghana, analysing critically the connotations of the concept, sources and acquisition of wisdom in the OT vis-à-vis those of the Akan ethnic groups of Ghana. Through a comparative analysis, it attempts to describe how the OT concept of wisdom could be understood with the help of its parallels in Akan, regardless of their disconnections. It discovers that the Akan concept of wisdom can be of help in the interpretation of wisdom in the OT, but it cannot fully explain it. The paper pinpoints one of the challenges that interpreters are likely to encounter in the use of reader-centred approaches of biblical hermeneutics.
\end{abstract}

KEYWORDS: Wisdom, Israel, Old Testament, Wisdom Literature, Akan, Culture.

\section{A INTRODUCTION}

Elements of culture differ from one society to the other. Different cultures have diverse interpretations of symbols and concepts. Interpreting symbols and concepts from one culture to the other should be done therefore in such a way

* Submitted: 05/12/2018; peer-reviewed: 17/07/2020; accepted: 25/08/2020. Emmanuel K. E. Antwi, Isaac F. Adjei and Joseph K. Asuming, "Understanding Wisdom in the Old Testament through Its Akan (Ghana) Parallels: Linkages and Disconnections," Old Testament Essays 33 no. 3 (2020): 408-427. DOI: https://doi.org/10.17159/2312-3621/2020/v33n3a4.

1 We acknowledge the assistance of our students from KNUST, St. Peter's Regional Seminary, Pedu-Cape Coast and St. Gregory Seminary, Parkoso-Kumasi, who joined our group discussions and provided much information on wisdom in Ghanaian cultures. Some of the biblical quotations follow the translation of the New Revised Standard Version. 
that their meanings are not lost in the context of their respective cultures. The Old Testament (OT) is written within the cultural background of ancient Israel in the ancient Near East. Some parts of Africa such as Egypt and Cush (Ethiopia) appear in the OT because they were known to the biblical writers. "Africa" known at the time of the OT is not the same "Africa" today-geographically and culturally. Though the sacred writers' interest was in addressing Israel, the word of God is also addressed to all those who share in the faith of ancient Israel either in part or in full. ${ }^{2}$ The Judeo-Christian scriptures continue to address most cultures of the world, even though they do not directly reflect their traditional beliefs, norms and values.

The Bible becomes more meaningful to its audience when it is interpreted in such a way that the audience is able to perceive the imageries and the concepts present in the text in their own culture. In other words, interpreting the Bible within the context of the present reader becomes an indispensable tool in helping the reader understand its message within his or her cultural environment. The Bible can be brought home to the present reader through contextualisation. ${ }^{3}$ Nonetheless, one cannot transfer the connotations of concepts in one's culture onto those of ancient Israel presented in the sacred scriptures. However, one cannot do away entirely with meanings of the concepts in one's culture when it comes to the interpretation of concepts in the Judeo-Christian scriptures. Caution must nonetheless be taken so as not to change the perspective of the text intended by the biblical narrator within his context and impose one's own cultural meanings into the text. ${ }^{4}$ Like the popular adage about teaching, "we teach from the known to the unknown," we may understand certain OT concepts through a better understanding of their equivalence in our own culture. "Wisdom" in the OT is one concept that could be used to illustrate this point.

The concept of wisdom is quite elusive in its definition. Various cultures have their unique notions of wisdom. Due to its abstractness, "wisdom" is explained with several related terms and descriptions in several cultures and religions. Wisdom is not restricted to any one particular society, group or culture; it is found in the cultures of the ancient Near East as well as of the Ghanaian peoples. However, the manifestations and connotations of wisdom may differ from one culture to the other. How then does one interpret OT wisdom using similar concepts from one's culture? To answer this question, we will seek to

2 Cf. Ben E. Zvi, "Towards an Integrative Study of the Production of Authoritative Books in Ancient Israel," in The Production of Prophecy: Constructing Prophecy (eds. Edelman D and Ben E Zvi; London: Equinox Publishing, 2009), 19.

3 Cf. A. O. Idamarhare, "Africentric Hermeneutics: Methodology towards Decolonizing Biblical Studies in Africa," Journal of Sociology, Psychology and Anthropology in Practice VI/1 (2014): 44-45.

4 Cf. George Ossom-Batsa, "African Interpretation of the Bible in Communicative Perspective," Ghana Bulletin of Theology II (July 2007): 101. 
demonstrate how wisdom in the OT could be understood through its Akan parallels, while respecting their disconnections and differences.

\section{B WISDOM IN THE OLD TESTAMENT 1 Definition of Wisdom}

As in other cultures, it is difficult to define wisdom in the OT. ${ }^{5}$ Some have attempted to define wisdom by describing some aspects of it without necessarily arriving at a precise or exact meaning. Hunter affirms that "people who are wise manifest their wisdom in all sorts of ways, but the quality itself resists direct observation. Rather like the wind, we know it by what it does, rather than by what it is." 6 This indicates that just as we cannot describe the wind by its exact nature, but we describe its nature by its effect on the environment, one can describe and define wisdom by its effects and manifestations. It is thus an abstract and innate quality, which is indescribable by its very nature but describable in what it produces. Murphy affirms that "wisdom does not represent the actions of God in Israel; it deals with daily human experience in the good world created by God."7 This implies that wisdom is attainable through daily experience in the created order. In this regard, one can affirm that the accumulation of human experience could amount to wisdom. As Crenshaw states,

The reasoned search for specific ways to ensure personal well-being in everyday life, to make sense of extreme adversity and vexing anomalies, and to transmit this hard-earned knowledge so that successive generations will embody it - wisdom - is universal. ${ }^{8}$

He notes the transmission of the accumulated experience, which amounts to wisdom and its universality. The universal nature of wisdom is similarly acknowledged by O'Connor who affirms the international nature of wisdom. ${ }^{9}$

The OT uses the Hebrew word hokhmah for wisdom. Hunter in defining hokhmah in the OT gives various meanings. ${ }^{10} \mathrm{He}$ derives six different connotations from the word, citing relevant examples to explain them. These are in reference to technical skills, administrative skills, King Solomon's gift, native wit, lifelong learning and an ethical and religious quality. These levels of meaning of wisdom describe the areas in which one can talk of wisdom in the

5 Kathleen M. O'Connor, The Wisdom Literature (Wilmington: Michael Glazier, 1988), 23.

6 Alastair Hunter, Wisdom Literature (London: SCM Press, 2006), 4.

7 Roland E. Murphy, The Tree of Life: An Exploration of Biblical Wisdom Literature (Grand Rapids: Eerdmans, 2002), 1.

8 James L. Crenshaw, Old Testament Wisdom: An Introduction (Louisville: John Knox Press, 1998), 3.

9 O'Connor, The Wisdom Literature, 23-24.

10 Hunter, Wisdom Literature, 9-20. 
OT. For instance, the artisans who are to make the sacred vestments for Aaron as attested in Exodus 28:2-4 are those that have been endowed with the spirit of wisdom - ruach hokhmah. Some English translations render ruach hokhmah as "skill" instead of the "spirit of wisdom." In 1 Kings 7:14, Hiram of Tyre is described as endowed with wisdom and a worker in brass. Some sailors of Tyre are also described in Ezekiel 27:8-9 as wise. Due to the possession of wisdom, they are able to exhibit the required skills in their professions. Though OT theologians do not precisely define wisdom, they describe what it is and point to the consequences of its possession.

\section{Sources and Acquisition of Wisdom in the Old Testament}

The OT bears witness to the sources of wisdom among the people of ancient Israel. Like other nations of the ancient Near East that acknowledged that wisdom belonged to their gods, ${ }^{12}$ Israel saw its God as the possessor and source of wisdom. True wisdom is divine wisdom since God is seen as the one possessing true wisdom, which cannot be attained solely through human efforts. Anderson acknowledges the charismatic nature of wisdom. ${ }^{13}$ It is seen in this context as a gift given by God to human beings. He explains that wisdom was a divine gift and "not just a human ability based on superior intelligence, serious study, or long years of experience." 14 Soggin defines hokhmah as "the divine cosmic wisdom for which all human beings must search with every means at their disposal." 15 Like Anderson, he shares the view that wisdom is divine and humankind can share in this wisdom. Wisdom is seen as an attribute of God. Human beings can share in this divine cosmic wisdom through their search and quest for this wisdom.

The book of Proverbs affirms the possibility of attaining wisdom through the fear of God. ${ }^{16}$ The theme of the fear of God and the acquisition of wisdom runs through the wisdom books. In most of the wisdom literature in which such theme occurs, one element stands out clearly, which is that Israel saw the fear of God as the source of human acquisition of wisdom. Proverbs 1:7 and 9:10 state that the fear of YHWH is the beginning of wisdom. In this case, the reverential fear of God and the observance of his commandments will help one attain

11 See New Jerusalem Bible (1985), New Revised Standard Version (1989), New American Bible (2010), English Standard Version (2007), etcetera.

12 Cf. Richard J. Clifford, The Wisdom Literature (Nashville: Abingdon Press, 1998), 25.

13 Bernhard W. Anderson, The Living World of the Old Testament (Harlow: Longman 1988), 572.

14 Anderson, The Living World of the Old Testament, 572. Cf. also Exodus 31:1-5; Proverbs 1:21, 2:6; 1 Kings 3:9-12; and Daniel 1:17.

15 Alberto J. Soggin, Introduction to the Old Testament (3rd ed.; Louisville: Westminster, 1989), 438.

16 Proverbs 2:1-5. 
wisdom. Ecclesiastes 1:12-18; 8:16-17 and Job 28:12-14; 20-22 point to the difficulty encountered in seeking for wisdom. Thus, one cannot attain wisdom by only human means. Solomon's wisdom is attributed to God, since he prayed for the wisdom to execute discernment and judgement. ${ }^{17}$

From Hunter's analysis of hokhmah, we identify various areas whereby wisdom could be attained. ${ }^{18}$ Hunter affirms that wisdom is a gift from God. King Solomon was endowed with this gift as recorded in 1 Kings 5:9-14 (4:29-34). His wisdom is said to have surpassed the wisdom of all the people of the East and Egypt. ${ }^{19}$ Those who were endowed with special technical and pragmatic skills were said to be wise. Exodus 28:2-4 and Ezekiel 27:8-9 are some of the proof texts for this form of wisdom. Artisans needed special wisdom to carry out their profession. Another important area that Hunter mentions is the field of administrative skills. Those figures mentioned in the OT as having helped in advisory roles are considered wise. Examples of such characters are Joseph, Esther and Daniel. ${ }^{20}$

The wisdom literature of Israel shows that wisdom could be acquired through experience and observation. One can attain wisdom through lifelong learning. The accumulated knowledge through lifelong learning is further transmitted to others. The sages in Israel imparted wisdom to their pupils. In much the same way, children learnt a lot from the informal education given to them by their parents. It must be noted that an Israelite's way of life was influenced by his or her religion. Hunter considers native wit as one of the connotations of hokhmah. He cites Exodus 1:10 and 2 Samuel 13:1 which respectively describe the action of Pharaoh and the rape of Tamar. This type of wisdom mentioned in the OT led to evil. Surprisingly, however, it is included as another type of wisdom. Those who neglect wisdom are seen to be foolish.

Wisdom was transmitted in Israel through family, clans, royal courts, schools of instruction or discipline and wisdom. ${ }^{21}$ It was the duty of the families, tribes or clans to train the youth to conduct their lives to conform to the societal norms. ${ }^{22}$ They sought to protect their youth through instructions to help them avoid evil and destructive behaviour. In doing so, they did not exclude the moral teachings of their religion. Teachings of YHWH were not excluded from their

17 Cf. Stephen L. Harris, Understanding the Bible (Mountain View: Mayfield Publishing Company 2000), 242. See 1 Kings 5:9-14 (1 Kings 4:29-34).

18 Hunter, Wisdom Literature, 9-20.

191 Kings 4:30. In the Masoretic text and other English versions, it is found in 1 Kings 5:9-10.

20 Genesis 41:33 and Daniel 1:20.

21 Cf. Katharine Dell, "Wisdom in the Old Testament," in The New Interpreter's Dictionary of the Bible, vol. V (ed. Katharine Doob Sakenfeld; Nashville: Abingdon Press, 2009), 870.

22 Cf. Crenshaw, Old Testament Wisdom, 77-78; Jeremiah 35:14. 
family values. The expression "listen, my son" found in the wisdom books could be used by a sage in reference to his pupil, but it signals its origin from the family setting. Some of the proverbs are centred on the training of the child. Examples are seen in Proverbs 23:13-14, 22, and 25. ${ }^{23}$ The instructions for the children or the youth might have later found their way into the sacred scriptures.

The sages reflected on the wisdom of God and came up with counsel for the people. ${ }^{24}$ Some of the sages were found in the royal court during the monarchical period. They helped in policy-making and administration of the nation. Mention could be made of Hushai and Ahithophel in the court of David. ${ }^{25}$ The stories of Joseph and Daniel are evidence of this type of wisdom. The attestation of oik $\omega \pi \alpha 1 \delta \varepsilon i ́ \alpha_{\varsigma}$ "bêt midrāš" (house of instruction, training, discipline) in Sirach (Ecclesiasticus) 51:23 points to the existence of a school to train the youth at the time of its writing. ${ }^{26}$ Sirach is one of the deutero-canonical books and scholars believe that it was written very late with Greek influence. ${ }^{27}$ The Greeks had two types of training for children, namely, propaideia and paideia. ${ }^{28}$ Propaideia (preliminary education) was given at home by parents or, in a more elitist home, by an educated slave. Paideia was the education beyond the preliminary. It was education outside the home or the beginning of the formal education. It is possible that Israel also had such schools, which were not purely secular but included certain elements of their religion, to train the youth. ${ }^{29}$

The concept of wisdom in ancient Israel, its acquisition and consequences of its possession, have come down to us in the form of its wisdom tradition, some of which are preserved in the OT. We identify different genres in OT wisdom literature, which help mediate the meaning of the texts. Understanding the various genres is necessary to unravel the meaning and implication of wisdom literature. Some of the genres are proverbs, witty sayings, religious maxims, aphorisms, paradoxes, riddles, allegories, hymns, autobiographical narratives and tractates. Some of the genres overlap and are synonymous. For instance,

23 "Do not hold back discipline from the child, although you beat him with the rod, he will not die" (Prov 23:13 NAS). Foolishness is bound up in the heart of a child; the rod of discipline will remove it far from him. (Prov 22:15 NAS) He who spares his rod hates his son, but he who loves him disciplines him diligently (cf. Prov 13:24 NAS).

24 Cf. Ezekiel 7:26; 2 Samuel 14:21 and 16:23; 20:14-22.

25 Cf. Crenshaw, Old Testament Wisdom, 21, 42; 2 Samuel 16:15-23; 17:6-15.

26 Cf. Murphy, The Tree of Life, 3.

27 Ben Sira possibly depended on Greek philosophy and the great Alexandrian Jewish philosopher Philo. Harris, Understanding the Bible, 242; Hunter, Wisdom Literature, 40 .

28 Ben Witherington III, "Education in Greco-Roman World," in The World of the New Testament (eds. Joel B. Green and Lee Martin McDonald; Grand Rapids: Baker Academic 2013), 191.

29 Crenshaw, Old Testament Wisdom, 45; Cf. Soggin, Introduction to the Old Testament, 441. 
proverbs, witty sayings and aphorisms are short sayings emerging out of one's observation of human conduct, some of which arise out of one's reflection on nature. ${ }^{30}$ They are short statements about certain truths of life and nature. The concise and precise nature of the proverbs and aphorisms facilitate their memorisation. They usually express and recommend human conducts which are acceptable in the society.

When one follows the wise instructions in these genres, one is able to "fit in with the social order." 31 Some examples are "Go to the ant, you lazybones; consider its ways, and be wise" (Prov 6:6), "Whoever corrects a scoffer wins abuse; whoever rebukes the wicked gets hurt" (Prov 9:7) and "Treasures gained by wickedness do not profit, but righteousness delivers from death" (Prov 10:2). ${ }^{32}$ Others, like riddles and allegories, are put in coded language having the literal and deduced meanings. One needs to deduce the hidden meaning by understanding the literal meaning and its inference. An example is found in Proverbs 5:15-17 about marital fidelity. There are biographical narratives in which someone's life experience is presented to teach the reader some moral and religious lessons for his or her life. An example is the story of Job, which is a disputation on divine justice. ${ }^{33}$ The stories of Joseph and Daniel, which are found outside the wisdom books, belong to this genre.

\section{WISDOM AMONG THE AKAN ${ }^{34}$}

The Akan is made up of different smaller ethnic groups, having similar culture and traditions but distinct Akan dialects. They are found in some parts of present Ghana and Côte d'Ivoire (Ivory Coast). ${ }^{35}$ The Akan are the largest ethnic group in Ghana ${ }^{36}$ and they are made up of, mainly, the Asante, Bono, Ahafo, Fante, Agona, Akyem, Akuapem, Akwamu, Denkyira, Kwawu, Wassa, Assen-Twifu, Nzima-Evalue, Ahanta and Sefwi. ${ }^{37}$ Most of the Akan dialects share vocabulary

30 B. C. Agyemang, A. M. Asumeng, B. Amponsah, "The Relevance of Ghanaian Akan Proverbs to Explanations of Contemporary Human Resource Principles and Corporate Values," Journal of Business Resaerch 9 (2015): 16-17.

31 Soggin, Introduction to the Old Testament, 440.

32 All the texts are taken from the New Revised Standard Version.

33 Cf. Clifford, The Wisdom Literature, 20.

34 Our students, who are from the various Akan ethnic groups in Ghana, helped to gather data for this section of the study through group discussions.

35 Peter Sarpong, Girls Nubility Rites in Ashanti (Ulm: Süddeutsche Verlagsgesellchaft, 1991), 1.

36 Agyemang et al., "The Relevance of Ghanaian Akan Proverbs," 17.

37 Peter Sarpong, Girls Nubility Rites in Ashanti (Ulm: Süddeutsche Verlagsgesellchaft, 1991), 1. Michael Ntiamoah, "Religious and Social Relevance of Nsuae (Oath Swearing) in Akan Indigenous Leadership Formation," E-journal of Religious and Theological Studies I/2 (2015), 124; Agyemang et al., "The Relevance of Ghanaian Akan Proverbs," 17. 
but with different accents and they are mutually intelligible. The Akan of West Africa are said to express "the absolute uniqueness of God" better than the Semites, Greeks and Romans. ${ }^{38}$ The Akan like the people of ancient Israel have traits of wisdom in their culture.

\section{Definition of Wisdom}

The concept of wisdom is prevalent in all Ghanaian cultures, ${ }^{39}$ particularly among the Akan. The translation of wisdom, its etymology and definition in the Akan dialects give a glimpse of the meaning of the concept among the respective Akan ethnic groups.

The Akan share the view that wisdom is not limited to one person but has a universal connotation. Nyansa is used to translate wisdom in some of the Akan dialects. It is derived from two Twi verbs nya and nsa. The word nya means "to acquire" while $n s a$ is derived from the negation of $s a$ meaning "finish." By implication, $n s a$ connotes something which does not finish, has no end or "is never exhausted," ${ }^{40}$ while nyansa connotes something, which when acquired becomes part and parcel of the person. Thus, the individual does what is expected of him without necessarily being guided by another person. There is another etymological meaning to nyansa, that is, wonya ansa, meaning, "you acquire before" and it is the truncated form of wonya ansa na yefa wo se onipa тиa"you acquire it before society accepts you as a (whole person) qualified member of the group."

Wisdom in Ebrosa (Aowin) and Nzema is ngyele and nwenle in Sefwi. Both of them have similar meanings, which can be expressed as "the ability to make good use of what you know." The Sefwi have another word for wisdom, nyanza, which sounds like nyansa in Twi. The wise person among the Akan is the one who is able to use the knowledge he or she possesses practically; not in a negative sense but in a positive manner.

38 Douglas E. Thomas, African Traditional Religion in the Modern World (Jefferson: McFarland and Company, 2005), 74.

39 Gyekye, exploring the nature of African philosophy, argues, "that philosophy is a universal intellectual activity that has been pursued by people of all cultures and that the propensity to raise fundamental questions about human experience can be found in peoples belonging to different cultures." Kwame Gyekye, An Essay on African Philosophical Thought: The Akan Conceptual Scheme (Philadelphia: Temple University Press, 1995), xiv.

40 Noah Komla Dzobo, “African Theory of Knowledge and Truth: The Ewe and Akan of West Africa," in The Triple Heritage of Contemporary Africa (ed. Noah Komla Dzobo and Simon Amegeshie-Viglo; Accra: Studio 7 Kat, 2005), 31. 


\section{Sources and Acquisition of Wisdom among the Akan}

The Akan ethnic groups acquire wisdom mainly through the deities, good elderly people, traditional sayings and proverbs, folktales, stories and myths, nature and arts and crafts.

The Supreme Being and deities are seen as the primary source of wisdom. It is the belief of the Akan that wisdom is a gift from the deities. In Akan traditional religion, the spiritual hierarchy reflects God, Asaase Yaa "the Earth Deity," gods, spirits and ancestors. ${ }^{41}$ This is manifested in their prayers known as apaec. The ethnic groups in Ghana ascribe to God as "all-knowing" or "omniscient." ${ }^{42}$ God is seen as the wisest and the source of wisdom. Hence, it is the belief that wisdom is divinely inspired. It is a gift given to humankind by the gods and that one can acquire wisdom by praying to the deities. The Akan traditional drummer precedes a prayer with the expression meresua momma me nhunu, which means, "aid me to become a master as I learn." This also affirms the role of the spiritual beings in the impartation of wisdom in Akan society. The belief also finds expression in Nzema as "Sonla enze nrelebe endila mosonlen mo," which means "Human beings are not wiser than the gods." This points to the belief that the gods possess more wisdom than human beings, and that one has to seek for what he or she does not have in terms of wisdom and knowledge from the deities. Among the Bono, wisdom is considered a gift from God, which he bestows on the individual that helps him or her to discern between what is good and evil in order to prevent mishaps and misfortunes in the community for the existence of peace and stability. Among the Bono, as among the other Akan groups, wisdom is not limited to one person, but has a universal connotation.

Furthermore, wisdom can be acquired through the interaction with good elderly people who are regarded as wise. Most Ghanaian societies associate wisdom with old age. ${ }^{43}$ This stems from the belief that because of their age they are closer to the deities and that they have also gone through the ups and downs of life, gathering different experiences at various stages of their life. There is the Akan saying, Wonni panin a, due, "Woe unto you if you do not have an elder in your family" and Panin dware wie a, na nsuo asa, "When an elder finishes bathing, there will be no water left." These two proverbs affirm the wisdom of the aged. This is epitomised in an Mfantse proverb as Adze a panyin tsena famu a ohu no, abofra fow dua mpo a onnhu, literally, "What an elderly person perceives while sitting, a child can never see even if he climbs a tree." This explains why in concrete decision-making, elders are first consulted. This

41 Cf. Gyekye, An Essay, 68-69; J. A. Boadi, Christianity or Traditional Beliefs and Customs? (Asafo-Kumasi: Humble Gate Publications, 2001), 10-13; Christopher Vecsey, "The Exception Who Proves the Rules: Ananse the Akan Trickster," Journal of Religion in Africa 12/3 (1981): 163-164.

42 Boadi, Christianity or Traditional Beliefs and Customs? 6.

43 Cf. Dzobo, "African Theory of Knowledge," 31. 
practice has given birth to the fixed expression, Yereksbisa nana aberewa, meaning, "We are going to consult the old lady." The 'old lady' in this fixed expression is not a person per se. Among the Akan, the 'old lady' in the homestead used to be the oldest and most experienced. She could be the grandmother and the mother of the family and could help in certain critical decision-making based on her life-long accumulated experience. The fixed expression is used during a difficult arbitration when the council finds it problematic to arrive at a solution and decides to consult few of the elders to come up with a resolution. This form of consultation, which has its historical and cultural antecedents, is labelled on an imaginary personified old lady. Women were believed to give wise judgement, due to their pacific nature and "in the past elders really did consult an old lady."44

An Asante adage abodwesc betoo aninton nwi implies that the young came to meet the elderly on earth. It must however be stressed that the Akan do not just associate wisdom with old age, but a life well-lived. In other words, respect is not automatically accorded to anyone by virtue of his or her old age but to elders who have established personal integrity by their moral life. The Akan have the saying, Wanyin agya ne nyansa ho, which literally means, "He has grown leaving his wisdom behind." This adage bears credence to the fact that old age does not necessarily guarantee being wise. Association with good and wise elders therefore becomes imperative in the acquisition of wisdom. ${ }^{45}$ By sitting at the feet of elders, wisdom is acquired as stories, proverbs, idioms and puzzles are told by the elders. Involvement in wise and thoughtful deliberation with the elders is seen as a way of acquiring wisdom.

Wisdom can be acquired through learning and experience. As one goes through life, one can acquire wisdom from everyday experience-life has a lot to teach us. The body of knowledge acquired from one's personal experience could become a source of wisdom for others. This is clearly underscored from an adage among the Asante - kwasea dua yenntia so mprenu, which means that even a fool learns from the past. The Akan believe that life itself is a school. Every moment brings new experience, teaching a new lesson to the individual. This is confirmed by the Mfantse proverb, Afotu nsakyera nyimpa gyede nsohwe, which shows that one learns more through experience than through pieces of advice. Some use the statement mesua nyansa meaning "I have learnt wisdom

44 Ibid., 32.

45 Ivan Karp and D. A. Masolo, in their discussion on "Knowledge and Discourse," assert that "individuals recount virtues by describing other people or statuses that possess them; by recounting the attributes of others and the relationships of friendship or kinship between self and other, individuals can assert virtues and achievements not directly but rather through associations they have made with other persons and roles." Thus, they raise their own social or moral standing to the same level as that of others they praise in speech. Ivan Karp and D.A Masolo, African Philosophy as Cultural Inquiry (Bloomington: Indiana University Press, 2000), 83-84. 
(lesson)" or akyerc me nyansa, "it has taught me wisdom (lesson)." Hence, the individual applies the knowledge and wisdom acquired in that experience.

Other sources of wisdom among Akan ethnic groups are found in their traditional songs, proverbs, sayings, puzzles, and idiomatic expressions. Ghanaians have a wide range of sayings, maxims, aphorisms and proverbs, which transmit the wisdom of the elders to the younger generation. An example is the Twi proverb, sba nyansafo yebu no be, yennka no ascm, literally, "we speak to a wise man in a proverb" which is similar to the English proverb "a word to the wise is enough." These sayings, among others found in the Akan language, transmit the wisdom of their ancestors about life to the future generation. Oral literature makes great impact on children who sit at the feet of the elders to listen to them. Several Akan proverbs express the wisdom of their respective communities. Opoku explains that virtues are communicated through proverbs and folktales with moral lessons. ${ }^{46}$ The Twi proverb, sba nyansafo yebu no be, yennka no asem, affirms this notion. Proverbs are used to address and correct people in a polite way so as not to offend them. ${ }^{47} \mathrm{~A}$ profane statement could be expressed in a proverb in such a way that it does not become offensive to the audience. ${ }^{48}$ Since proverbs are handed down from generation to generation, it is believed that they have some backing from the ancestors and that the living should adhere to them in different situations such as the settling of dispute. ${ }^{49}$ Due to the respect for societal norms and traditions, one is inclined to adhere to such proverbs as the standard norms.

Among the Akan of Ghana, wisdom is also acquired through careful observation of elements of creation. For example, farmers are able to observe the weather to determine the rainfall pattern and to know when to sow or plant crops. The element of wisdom is widely portrayed in what is known as "traditional science." In Ghana, it is fascinating to observe how the popular alcoholic drink, akpeteshie, is locally distilled, without the formal study of Chemistry. By one's critical observation of nature, he or she can draw wisdom from animate and inanimate things. For instance, some observe the life of some creatures to draw wisdom from them. One creature that is associated with wisdom is Kwaku Ananse (the spider), which is used in numerous stories and folktales of the Akan. The spider assumes the role of the divine and of human beings in the folklores,

46 Asare K. Opoku, West African Traditional Religion (Kucena: Damien (Nig) Ltd. 1978), 158.

47 Cf. Steen J. Salm and Toyin Falola, Culture and Customs of Ghana (London: Greenwood Press, 2002), 60.

48 Cf. Steve Kquofi, Peace Amate and Emmanuel Tabi-Agyei, "Symbolic

Representation and Socio-cultural Significance of Selected Akan Proverbs in Ghana," Research on Humanities and Social Sciences 3/1 (2013): 86-87.

49 Cf. Opoku, West African Traditional Religion, 158, 162. 
and its function indicates success or failure in life, from which the hearer is supposed to acquire wisdom for his life. ${ }^{50}$ Mbiti observes that:

The spider, though a small creature, appears in many myths and stories. Among the Akan, particularly the Ashanti, the spider symbolizes "wisdom" and for that reason, God is given the title, "Ananse Kokroko" which means "the Great Spider, that is the Wise One." "51

Among the Akan, "most important virtues are either couched in proverbs or expressed in the form of a folk-tale with a moral to it." 52 Salm and Falola share the view that folktales use animal imageries to impart a moral lesson. ${ }^{53} \mathrm{Kwaku}$ Ananse stories are told to give moral lessons. Morals deduced from these proverbs and Ananse stories go a long way to inculcate into the listeners wisdom that influences their lives.

An essential aspect of every culture is its music, dance, arts and crafts. Among traditional Ghanaians, these can be considered sources of wisdom. ${ }^{54}$ Ghanaians, the Akan in particular, have symbols, which point to some philosophical thoughts. Some of these symbols include adinkra of the Akan and agama of the Ewe, which teach wisdom. ${ }^{55}$ For instance, the sankofa adinkra symbol, literally, "return and get it," implying "re-tracing our steps," 56 is a symbol of the importance of learning from the past. Another adinkra symbol is nkonsonksnson (chain links), which reminds everybody to contribute to communal development. Funtumfunafu dekycmfunafu, won afuru bom nanso wopere aduane ho, is symbolised by two intertwined (Siamese) crocodiles. These share a single stomach and yet they fight over food. This is a deep philosophical statement about a group of people with the same goal but fight one another. This is a "symbol of unity in diversity." 57 The adinkra symbols portray much wisdom of the Akan.

In traditional Akan societies, another important symbol is the drum, precisely the talking-drum that is used to communicate information and words of wisdom. According to Dankwa, there are many drums in the palace, but the

50 Vecsey, "The Exception Who Proves the Rules," 161-162.

51 John S. Mbiti, Introduction to African Religion (2nd ed.; London: Heineman Education Books, 1975), 51.

52 Opoku, West African Traditional Religion, 158.

53 Salm and Falola, Culture and Customs of Ghana, 60.

54 Cf. Prince S. Conteh, Essays in African Religion And Christianity (Accra: Cynergy Media Ent., 2014), 14-15.

55 Kquofi et al., "Symbolic Representation," 87-88.

56 Agyemang et al., "The Relevance of Ghanaian Akan Proverbs," 18.

57 Peter Achampong, Christian Values in Adinkra Symbols (Kumasi: University Printing Press, 2008), 16. 
talking-drum is a drum with a difference. The sound produced by beating the drum $^{58}$ is used to transmit important messages from one part of the territory to another. The talking-drum is used to sing praises of the Chief and his elders and to express condolences to bereaved families during funerals and other emotive expressions. ${ }^{59}$ Opoku also identifies the usefulness of the drum in the discourse of wisdom. ${ }^{60}$ For him, the language of the Akan talking-drum contains references to ethical ideas, as well as direct and straightforward moral instructions. The Ddomakoma kyercma (divine drummer) advises on his drum, playing some maxims and proverbs. He further explains that the skyercma (drummer), who symbolises knowledge and wisdom in Akan communities, plays the talkingdrums intermittently when cases are being tried in the Chief's court.

\section{A "Wise Person" among the Akan}

The deeds and actions of a person are essential in determining whether he or she can be considered wise. The wise person is prudent. He or she thinks thoroughly before speaking and the speech mostly provokes and elicits further thought. The wise person has vast and in-depth knowledge of history and traditions of culture, which in turn helps him or her to be sociable in the community. Wise people are humble, have a good knowledge of the "self" and are able to listen to the views of others. They have the quality of being patient, trustworthy, and live in true solidarity with others. People who express unconditional love and patriotism for their ethnic group and the gods are also seen as wise. This belief finds expression in the Nzema phrase, me Nyamenle ne me maanle, meaning, "my god and my country (nation or state)." People are considered wise because they sacrifice what they have for the good of their people and lead a moral life that is pleasing to the society. They find their identity among their people, knowing very well that their existence in the society is dependent on the existence of their people. ${ }^{61}$ The Akan who live such patriotic and exemplary life are greatly respected in the society.

Among the Akan, the benchmark for measuring nyansa manifests in daily discourse, dressing, adjudication and general behaviour. Nyansani "the wise person," is thus flawless in speech or has linguistic competence and exhibits good behaviour. The Akan believe that a wise person is the one who gives sound judgement. The wise person knows, understands and applies the social norms, customs and traditions of the land. This is epitomised in an Mfantse proverb inyim dze a, nnsce dze implying that, you do the right thing when you know the right thing to be done.

58 It is known as Tweneka in Asante.

59 Oseadeeyo Addo Dankwa III, The Institution of Chieftaincy in Ghana (Accra: Konrad Adenauer Foundation, 2004), 87.

60 Opoku, West African Traditional Religion, 158, 162.

61 Vecsey, "The Exception Who Proves the Rules," 165-166. 
In contrast to the above, people who have failed in life or who are unsuccessful are regarded as unwise. In Sefwi, such people are called kohwinia or sanzania, and in Nzema and Ebrosa, they are called mafemgbane. They are referred to as kohwini in Asante or sansanyi in Mfantse. Ultimately, these expressions connote deviancy. In most Ghanaian communities, people who exhibit the following attitudes are generally regarded as unwise - a disrespectful person; one who disregards the customs and traditions of the land; an immoral person; an elder who behaves like a child or a person who is unable to make good decisions; the lazy ones and those who do not accept corrections.

\section{WISDOM IN THE OLD TESTAMENT AND AMONG THE AKAN: LINKAGES AND DISCONNECTIONS}

From the ongoing discussion, several commonalties and some differences could be ascertained between wisdom in the OT and in some traditional Akan cultures. These could be seen in the definition, source and acquisition of wisdom. The commonalities could be used to help the Akan Bible reader to perceive the concept of biblical wisdom in his or her own culture. However, we are likely to find some elements of disconnection. Even though we cannot establish historical connections between wisdom in the OT and that of the Akan, we cannot deny their linkages. Although there are different cultures, human beings share a common humanity. Wisdom cannot be limited to only one culture as acknowledged by the worldview of the Akan.

The etymology and definitions of wisdom in the OT and Akan dialects do not precisely point to what wisdom is due to its abstractness. Wisdom is the human ability to relate and respond to the society and the environment. The ability to manage the environment and to create harmony within one's environment and the society stems from one's possession of wisdom. All the definitions point to the quality of wisdom, the consequences of possessing it and what it really does. This is reflected in some texts in the OT such as Deuteronomy 4:6; 34:9; 1 Kings 3:28 and Proverbs 28:26. Solomon's good governance is attributed to his hokhmah that he received from God (1 Kgs 3:28; 5:9-14 [4:2934]). Similarly, nyansa in the Akan dialects is defined mostly by its manifestation in behavioural activities. It signifies the permanent nature of knowledge that aids one to make proper discernment and judgement on his or her own. Nyansa among the Akan connotes the possession of an in-depth knowledge that is utilised in a positive manner. Without the manifestation of nyansa in prescribed activities, there is no determinant of the possession of wisdom. Thus, wisdom in these contexts is not defined precisely and concretely.

Akwasi Ampofo Agyei's song, Adwene nko, cnna nyansa nko, reflects the types of wisdom in contemporary Akan society. These are efie nyansa (natural wisdom), which includes the knowledge of cultural values and tradition and sukuu nyansa, which is acquired through modern formal education. The former is considered superior to the latter. Similar notion is expressed in Sirach 34:9 in 
which the educated person or the one who is exposed to other knowledge through travels is said to know many things, but the "one with much experience knows what he is talking about." This implies that the one exposed to foreign knowledge knows many things but the one with experience has practical knowledge. Like that of the Akan, practical knowledge emerging out of innate wisdom is seen in this context as superior to wisdom acquired through formal education.

Wisdom is abstract in language, and to remove it from its abstraction, it is often personified in the OT as though it had a concrete existence. The book of Proverbs personifies wisdom as a woman, prophetess and spokesperson of God in $1: 20-33 ; 8: 1-21$ and as a banquet giver in $9: 1-12$. Wisdom is seen as inviting the simple to come to know her and share in her value. Wisdom is thus presented as a person and given a personality. This helps the narratee to grasp the concept of wisdom in concrete terms. Personification is not unfamiliar to the Akan. There is personification for example in the Akan expression Ycreksbisa nana aberewa, which means literally, "We are going to consult the old lady." The 'old lady' in this fixed expression is not a person per se, as already noted. ${ }^{62}$ It is just a personified system of consultation, whereby the elders seek for wisdom in arriving at a decision.

Personification is also found in the folklores of the Akan. Animal imageries are used as characters in the folklores. They are represented as human beings and given a character that becomes a repository of wisdom and that invites the audience to share in the wisdom that the folklore communicates. The clearest examples are seen in the Akan folklores, legends, myths and proverbs in which the spider is the protagonist. The spider, Kweku Ananse, as explained earlier on, is a dominant character in most of the Akan folklores. In such stories, the spider is presented as a man, father, worker, et cetera. In addition to the spider being personified, the stories narrated around him conclude with a trait of wisdom that conveys moral lessons. One popular story has it that Kwaku Ananse gathered all the wisdom on earth and thought that apart from him no other person should be wise. ${ }^{63}$ He kept this wisdom and decided to hide it on top of a very tall tree. Unfortunately, he tied the pot of wisdom to his stomach, making it difficult for him to climb. Antikumah, his son, happened to be there and saw his father struggling to reach the top of the tree. He said to his father, "Father, why do you not tie the pot to your back instead?" Ananse at this point realised that the son too had wisdom. Out of frustration, Ananse held fast to the pot, but it fell and broke. From there, wisdom spread worldwide. The lesson deduced from this story is that one cannot claim monopoly of the possession of wisdom. The story is thus communicated to draw out lessons for the audience. Such stories are not unfamiliar in the OT world. The book of Job, for instance, is a narrative about

62 Dzobo, "African Theory of Knowledge," 32.

63 Cf. Vecsey, "The Exception Who Proves the Rules," 171. 
the figure of Job which conveys a message on the theology of individual retribution, suffering and divine justice to the audience. ${ }^{64}$

In Akan culture, wisdom is a divine gift. One can attain wisdom by praying to the gods. This must be understood in the context of the polytheistic religious traditions of the Akan. The Akan believe that the gods possess wisdom and can grant wisdom to humankind. Such a belief is reflected in Daniel 5:1114 in which the wisdom of Daniel was likened to the wisdom of the gods. Daniel was capable of interpreting the dream of King Belshazzar because he possessed the spirit of the gods which meant that he possessed wisdom as well. Though Daniel's wisdom was from God, due to the polytheistic background of the Babylonians, they attributed it to the gods. God was the source of wisdom in ancient Israel. Solomon's prayer to God made him the wisest in the ancient Near East according to 2 Chronicles 1:6-12 and 1 Kings 10:23-24. Job 12:13 affirms that God is the source of wisdom. The book of Proverbs also presents the fear of YHWH as a means through which one can acquire wisdom. Ancient Israel, unlike its surrounding nations and traditional Akan groups who were polytheistic, did not attribute wisdom to the lesser deities.

Furthermore, one could acquire wisdom through experience in the Akan cultures examined. In the case of the OT, reference is always made to God, though wisdom can also be acquired. The elderly among the Akan are believed to be wise through their diverse experiences of life. The need to imitate the steps of the wise is expressed in the Mfantse proverb, Abofra a ohu ne nsa ho hohor no snye mpanyimfo dzidzi, literally, "A child who learns to wash his or her hands eats with the elders." This reinforces the idea that the youth could acquire wisdom through their encounter with the aged who are believed to be wise. This notion finds its parallels in Proverbs 13:20 and 15:31. In Proverbs 13:20, the one who joins the company of the wise becomes wise whereas the companion of fools suffers harm. Proverbs 15:31 states that the one who heeds good advice is counted among the wise. Clearly, Israelite families sought to inculcate moral values of their culture to their young ones through informal education at home. Proverbs 8:33 exhorts the reader not to neglect instruction and to be wise. This is the case as well among the Akan.

Among the Akan, wisdom is transmitted through various genres such as proverbs, songs, fixed expressions and other traditional sayings. These are also attested in the wisdom tradition of ancient Israel and are similar in both content and form. It is not surprising that one of the wisdom books is named the book of Proverbs. Proverbs are "wise philosophical expressions" 65 and are highly significant in the Akan culture. They were composed out of practical life experiences and handed down from generation to generation, having become "a

64 Clifford, The Wisdom Literature, 73-75.

65 Kquofi et al, "Symbolic Representation and Socio-cultural Significance of Selected Akan Proverbs in Ghana", 86. 
repository of social norms and values as well as an embodiment of culture and tradition." 66 They contain wisdom necessary for one's life in the community just like in the OT times. For instance, the Akan proverb Wodi ascmpa a, wonyini $k y \varepsilon$, meaning, "If you are in the habit of doing what is right, you will live long," finds resemblance parallel in Proverbs 28:16 which points out that the one who abhors injustice will enjoy long life.

Wisdom is an integral element of growth in the Akan society and everyone is expected to have it. Failure to use one's wisdom and not putting into practice the knowledge acquired render a person unwise. On the other hand, upholding and cherishing wisdom qualifies one as a wise person. In most Akan traditional institutions, the one who is wise lives a life worthy of emulation, and even after death, such a person qualifies to be considered an ancestor of the clan, and of the society at large. ${ }^{67}$ Acquisition of wisdom through nature is common to both the OT and Akan cultures. Nature determines what one can produce within his or her environment. Determining and observing seasons, animals and plants, and coming up with standard religious and practical maxims about life is common to most cultures. Most proverbs are deduced from the observation of nature in the OT and Ghanaian cultures. Solomon is characterised as a wise person in 1 Kings 4:30-34. He composed many proverbs and songs and talked about trees and animals. A Ghanaian chief or linguist is said to be wise if he or she is able to speak in proverbs, most of which are derived from nature and daily experiences.

Although traditional Ghanaian ethnic groups, like many other African societies, do not have codified sacred books like the OT in which we find the wisdom tradition of ancient Israel, the cultural artefacts, music, drumming and dances and symbols such as the adinkra of the Asante, as already explained, portray the traits of their wisdom traditions. Mbiti notes that, "African Religion has no scriptures or holy books. It is written in the history, the hearts and experiences of the people." 68 With this statement, Mbiti indicates that religious values and traditions of African peoples are written in their histories, previously in oral form, and cultural experiences. Ghanaian proverbs, riddles, beliefs, music, ceremonies, myths and legends that have been handed down from one generation to the other, for instance, are vehicles of their religious and wisdom traditions. ${ }^{69}$

66 Agyemang et al., "The Relevance of Ghanaian Akan Proverbs," 16-17; Kquofi et al., "Symbolic Representation and Socio-cultural Significance of Selected Akan Proverbs in Ghana," Research on Humanities and Social Sciences 3/1 (2013): 86-87.

67 Peter Sarpong, Ghana in Retrospect: Some Aspects of Ghanaian Culture (Tema: Ghana Publishing Corporation, 1974), 34-36.

68 Mbiti, Introduction to African Religion, 17.

69 Cf. Gyekye, An Essay, 13-15; Agyemang et al., "The Relevance of Ghanaian Akan Proverbs," 16. 
Many people possess knowledge and skills but not everyone could be referred to as being wise. Our discussion of the wise among the Akan shows that the wise person is the one who has good knowledge of the history and traditions of the culture. Such knowledge should help the individual to socialise well in his or her community and to find harmony within the environment. In addition, those who exhibit the true spirit of patriotism are also said to be wise. Similarly, the wise person in ancient Israel is exhorted to have the fear of YHWH and move away from evil. The life of Israel, just like that of the traditional Akan ethnic groups (though polytheistic), was inextricably bound to its faith in its God. To be able to develop the true fear of YHWH, the people were enjoined to respect and obey the laws and traditions that were given to them by God. ${ }^{70}$ Those who refused to listen to instructions and did not know the way of YHWH were regarded as unwise as reflected in Proverbs 15:5 and Wisdom 13:1.

\section{E CONCLUSION}

One cannot deny that wisdom is inherent in all cultures and manifests in diverse forms. The comparative survey of the concept and practice of wisdom between Akan cultures and the OT testifies to this fact. From the ongoing discussion, one can surmise that though we cannot precisely trace the historical connections between the concepts of wisdom in traditional Akan cultures and the OT, some linkages are traceable. These are seen in the areas of the definition, sources and acquisition of wisdom. Wisdom, though abstract, is presented in concrete imageries in all the traditions to make it more comprehensible. Ancient Israel did not attribute wisdom to the lesser deities. The Akan attributed wisdom to the lesser deities because of its acknowledgement of the deities in their religion. Traits of wisdom traditions of ancient Israel are codified and accepted as sacred in the OT. Though we cannot argue that the concept of wisdom of the Akan is the same as Israelite wisdom, we can identify some similarities in the two. Wisdom of the Akan is contained in certain cultural elements such as artefacts, music, dance, drumming and symbols, and wisdom in the OT could be understood using the Akan lens. However, careful attention must be paid to their disjunctions. In this regard, caution must be taken when interpreting biblical concepts in the light of the meanings and connotations of their parallels in the reader's culture in order not to lose the sense implied by the source text.

\section{F BIBLIOGRAPHY}

Achampong, Peter. Christian Values in Adinkra Symbols. Kumasi: University Printing Press, 2008.

Addo Dankwa III, Oseadeeyo. The Institution of Chieftaincy in Ghana. Accra: Konrad Adenauer Foundation, 2004.

70 See Proverbs 1:8; 4:13; 6:23; and 19:20. 
Agyemang, Badu. C., A.M. Asumeng, and B. Amponsah. "The Relevance of Ghanaian Akan Proverbs to Explanations of Contemporary Human Resource Principles and Corporate Values." Journal of Business Research 9 (2015): 16-27.

Anderson, Bernhard W. The Living World of the Old Testament. Harlow: Longman, 1988.

Boadi, J. A. Christianity of Traditional Beliefs and Customs? Asafo-Kumasi: Humble Gate Publications, 2001.

Clifford, Richard J. The Wisdom Literature. Nashville: Abingdon Press, 1998.

Conteh, S. Prince. Essays in African Religion and Christianity. Accra: Cynergy Media, 2014.

Crenshaw, James L. Old Testament Wisdom: An Introduction. Louisville: John Knox Press, 1998.

Dell, Katharine. "Wisdom in the Old Testament." Pages 869-875 in The New Interpreter's Dictionary of the Bible, Volume V. Edited by Katharine Doob Sakenfeld. Nashville: Abingdon Press, 2009.

Dzobo, Noah Komla. "African Theory of Knowledge and Truth: The Ewe and Akan of West Africa." Pages 27-49 in The Triple Heritage of Contemporary Africa. Edited by Noah Komla Dzobo and Simon Amegeshie-Viglo. Accra: Studio 7 Kat, 2005.

Gyekye, Kwame. An Essay on African Philosophical Thought: The Akan Conceptual Scheme. Philadelphia: Temple University Press, 1995.

Harris, Stephen L. Understanding the Bible. Mountain View: Mayfield Publishing Company, 2000.

Hunter, Alastair. Wisdom Literature. London: SCM Press, 2006.

Idamarhare, A. O. "Africentric Hermeneutics: Methodology towards Decolonizing Biblical Studies in Africa." Journal of Sociology, Psychology and Anthropology in Practice VI/1 (2014): 44-54.

Karp, Ivan and D.A. Masolo. African Philosophy as Cultural Inquiry. Bloomington: Indiana University Press, 2000.

Kquofi, Steve, Peace Amate and Emmanuel Tabi-Agyei. "Symbolic Representation and Socio-cultural Significance of Selected Akan Proverbs in Ghana." Research on Humanities and Social Sciences 3/1 (2013): 86-98.

Mbiti, John S. Introduction to African Religion. 2nd Edition. London: Heinemann Education Books, 1975.

Murphy, Roland E. The Tree of Life: An Exploration of Biblical Wisdom Literature. Grand Rapids: Eerdmans, 2002.

Ntiamoah, Michael. "Religious and Social Relevance of Nsuae (Oath Swearing) in Akan Indigenous Leadership Formation." E-journal of Religious and Theological Studies I/2 (2015): $122-139$.

O'Connor, Kathleen M. The Wisdom Literature. Wilmington: Michael Glazier, 1988.

Opoku, Asare K. West African Traditional Religion. Kucena: Damien (Nig) Ltd., 1978.

Salm, J. Steven, and Toyin Falola. Culture and Customs of Ghana. London: Greenwood Press, 2002.

Sarpong, Peter. Ghana in Retrospect: Some Aspects of Ghanaian Culture. Tema: Ghana Publishing Corporation, 1974.

Sarpong, Peter. Girls Nubility Rites in Ashanti. Ulm: Süddeutsche Verlagsgesellchaft, 1991. 
Soggin, J. Alberto. Introduction to the Old Testament. 3rd Edition. Louisville: Westminster, 1989.

Thomas, Douglas E. African Traditional Religion in the Modern World. Jefferson: McFarland and Company, 2005.

Vecsey, Christopher. "The Exception Who Proves the Rules: Ananse the Akan Trickster." Journal of Religion in Africa 12/3 (1981): 161-177.

Witherington III, Ben. "Education in Greco-Roman World." Pages 188-194 in The World of the New Testament. Edited by Joel B. Green and Lee Martin McDonald ,. Grand Rapids: Baker Academic, 2013.

Zvi, Ben E. "Towards an Integrative Study of the Production of Authoritative Books in Ancient Israel." Pages 15-28 in The Production of Prophecy: Constructing Prophecy and Prophets in Yehud. Edited by Edelman D. and Ben E. Zvi,. London: Equinox Publishing Ltd., 2009.

Emmanuel Kojo Ennin Antwi, Senior Lecturer, Department of Religious Studies, Kwame Nkrumah University of Science and Technology, Kumasi, Ghana, https://orcid.org/0000-0003-0542-6492. Email Address: kojoantwi999@yahoo.de.

Isaac Forson Adjei, Lecturer, Department of Languages and Communication Science, Kwame Nkrumah University of Science and Technology, Kumasi, Ghana https://orcid.org/0000-0001-8867-2503. Email Address: iadjeiforson@yahoo.com.

Joseph Kwadwo Asuming, Former Teaching Assistant, Department of Religious Studies, Kwame Nkrumah University of Science and Technology, Kumasi, Ghana (Currently MPhil Candidate, University of Ghana, Legon, Accra) https://orcid.org/0000-0002-9915-6202. Email Address: jasuming6@gmail.com. 